\title{
【委員会報告】
}

\section{性能設計のための土の繰返しせん断試験の標準化 その2 標準試験法の提案 \\ STANDARD CYCLIC SHEAR TEST FOR PERFORMANCE BASED DESIGN PART 2 PROPOSAL OF STANDARD TEST METHOD}

\author{
地震工学委員会・性能設計に対応した繰返しせん断試験検討小委員会 \\ Subcommittee on Cyclic Shear Test for Performance Based Design, JSCE Earthquake Engineering Committee
}

\section{1.はじめに}

1995年兵庫県南部地震では，当時の設計で考慮してい た地震動より大きな地震動が作用したということから， 土木関係の多くの設計指針で設計用入力地震動が大きく なった.この際，多くの設計指針では，構造物のライフ サイクル中にくる可能性が高い，いわゆるレベル1地震 動については被害が発生しないこと，まれにしか起こら ないが，起こると非常に大きい地震動となる，いわゆる レベル2地震動については，ある程度の被害は許容する という，二段階設計が取り入れられるようになり，性能 設計といら考えが取り入れられるようになった.

これに伴って，構造物への入力地震動や，性能設計 で重要な地盤や土構造物の変位を精度良く求めるための, 地盤の地震応答解析も多く行われるようになってきた.

地震応答解析に用いる地盤の力学特性は, 繰返しせ ん断試験と呼ばれ，その方法は，文献1)に基づいて行わ れるのが一般的である. 繰返しせん断試験は1970年代に 基本的な方法が作られ，その後ほとんど変わらないで使 われてきた。当時は，SHAKE ${ }^{2)}$ と呼ばれる等価線形化解 析が唯一の解析法であり，それに適合寸る試験法として は妥当なものと考えられていた。しかし，その後，地震 応答解析は，逐次積分に基づく非線形解析，さらには液 状化解析と多くの解析法が実務で行われるようになった。 また，これに対応するように多くの構成モデルが作られ てきた.しかし，現在の試験法がこれらの構成モデルに 必要な力学特性を表現できているのかというような議論 は行われてこなかった様に考えられる．前報3では逐次 積分に基づく非線形解析に用いる応力一ひずみ関係とし て現在標準的に行われている試験法を検討し，その問題 点を指摘した.

非線形解析や液状化解析では多くの構成モデルが提 案されており，そのすべてに適用できる試験法は困難で ある，従って，試験法は，多くの構成モデルで用いるこ とのできる基本的な試験と，個別の構成モデルに必要な
特殊な試験法に分けるのが妥当と考えられる．本論では， このうち基本的な試験法を提案するものである。この様 な試験では，例えば，従来と全く異なる試験法を提案し ても実務では取り入れられない事が多いと考えられる. そこで，本論では，現行の方法をなるべく生かす基本的 な試験法を提案している.

\section{2. 現行の繰返しせん断試験の概要と問題点}

現在多く行われている試験法の問題点については, すでに前報3で詳細に論じた。ここでは，それをまとめ て示す

\section{(1) 現行の繰返しせん断試験の概要}

土の繰返しせん断特性は繰返しせん断試験で求めら れる1)。試験結果は，せん断ひずみ $\gamma$ に依存した割線剛性 $G$ と減衰定数 $h$ で表現され, $G-\gamma, h-\gamma$ 関係として表現さ れる。このような試験は，1970年代の初頭に Seed と

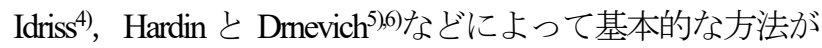
示され，大きく変わることなく，現在まで使われている， 文献1)では色々な載荷方法が示されているが，現在最も 一般的に行われている方法は以下のようなものである.

\section{a) ステージテスト}

小さい振幅の試験から始め，次第に振幅を大きくし ていく試験法である。一つの試料で小さいひずみ振幅か ら大きいひずみ振幅までの試験が行える。

\section{b) 非排水条件}

地震の継続時間は短いことから，その間の間隙水の 移動はほとんどないと考えられるので，試験は非排水条 件で行われる，ただし，非排水条件とはいえ，各ステー ジの間ではそのステージで発生した間隙水圧を消散させ ている.

\section{C) 応力制御}

応力制御とは試験の載荷方法を制御する方法の一種 であるが，二つの使われ方がある。一つは，載荷の応力 
増分の与え方，もう一つは一サイクルの振幅を応力で設 定する方法である.ここで増分とはある状態から次の状 態に移行する（以下，ステップと呼ぶ）際に試験機から 送られるシグナルで応力制御では応力が，ひずみ制御で はひずみで設定される.

現行ではどちらも応力で与えているので区別する必 要は生じないが，本来この二つは別の使い方である，そ こで，本論では振幅を制御する方法を応力振幅制御，ひ ずみ振幅制御というように呼んで，次のステップを制御 する方法と区別することにする.

\section{d) 繰返し数}

11サイクルの繰返し載荷を行い，10サイクル目の履歴 曲線から除荷点を結びせん断剛性 $G$ を，履歴曲線の面 積から減衰定数 $h$ を計算し，これらをひずみの関数とし て表現する.

\section{e) 初期応力}

有効上載圧が等方的に作用した状態を初期状態とし て載荷する.

\section{(2) 現在の試験法が抱える問題点のまとめ a) 大ひずみ領域のデータの不足}

図-1は，文献7)に示されるひずみ領域と材料の性質の 関係図である。これによれば，大ひずみ領域は，0.1\%〜 3\%程度のひずみと定義されている，本論でも，図-1に 従って，このひずみ領域の名前を使うことにする.

繰返しせん断試験で10サイクル目の履歴曲線を用いる のは, 履歴曲線が安定した状態を採用するためである. しかし, 安定という観点で試験法の適用性を考えると,

\begin{tabular}{|c|c|c|c|c|}
\hline \multirow{2}{*}{$\begin{array}{l}\text { Shear } \\
\text { strain }\end{array}$} & \multicolumn{4}{|c|}{$10^{-6} \quad 10^{-5}$} \\
\hline & $\begin{array}{l}\text { Small } \\
\text { strain }\end{array}$ & Medium strain & $\underset{\text { strain }}{\text { Large }}$ & $\begin{array}{l}\text { Failure } \\
\text { strain }\end{array}$ \\
\hline Elastic & \multicolumn{4}{|c|}{ 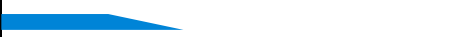 } \\
\hline Elasto-plastic & \multicolumn{4}{|c|}{$\longrightarrow$} \\
\hline Failure & \multicolumn{4}{|c|}{ 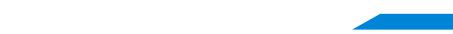 } \\
\hline $\begin{array}{c}\text { Effect of } \\
\text { load-repetition }\end{array}$ & \multicolumn{4}{|c|}{ 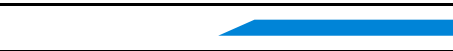 } \\
\hline $\begin{array}{c}\text { Effect of } \\
\text { loading rate }\end{array}$ & \\
\hline
\end{tabular}

図-1 ひずみの領域と材料の性質（文献7)より）
適用限界は0.1\%を少し超えるところ，すなわち，大ひず み域に入ったところまでと考えられる

一方, 液状化判定でよく用いられるひずみの判定は 三軸試験では両振幅5\%で，これを繰返しせん断試験に 用いられる片振幅せん断ひずみに換算すると $3.75 \%$ であ る.しかしながら, 繰返しせん断強度試験（液状化強度 試験）では，試験の目的から，強度に関する情報は出力 されているが，液状化に至る前の応力一ひずみ関係はそ れほど興味を持たれていない。

以上の様に，既往の試験では繰返しせん断試験の適 用範囲 $0.1 \%$ 少し越えるひずみから液状化強度試験で対 象としている数\%のひずみ域，すなわち，大ひずみ領域 の広い範囲の応力ーひずみ関係のデータは求められてい ない.

\section{b) 両ひずみ振幅と残留変形}

三軸試験では，ひずみは伸張方向にドリフトするこ とはよく知られている.しかし，この効果は現行の試験 法では考慮されていない.

図-2は一つの試験例である。この各ステージにおける 10サイクル目の履歴曲線を示したものが図-2(b)であり, 伸張方向にドリフトしていることがわかる．しかし，現 在の整理法ではそれぞれの履歴曲線の除荷点を結んで求 めているため, いわば，図-2(c)の様に履歴曲線の中心が 原点あるとして集めて, 図で点線で示したような応力一 ひずみ関係を求めているようなものであり，永久変位に 相当する残留変位が含まれていない．

\section{c) 10サイクルの繰返し}

実務の地震応答解析でよく用いられる $\mathrm{SHAKE}^{2}$ に代表 される等価線形解析では, 解析時間を通して力学特性は 一定である. 解析に必要な応力一ひずみ関係は全解析時 間を代表するものが適当であり, さらに解析は周波数領 域で行われることから, 定常化した履歴曲線が必要であ った.

しかしながら，最大応答はほとんどの場合，ひずみ が新しい領域に入った状態, すなわち，1サイクル目で 発生する. 従って, 最大值を精度良く求めたいのであれ ば，10サイクル目の挙動ではなく，1サイクル目の挙動

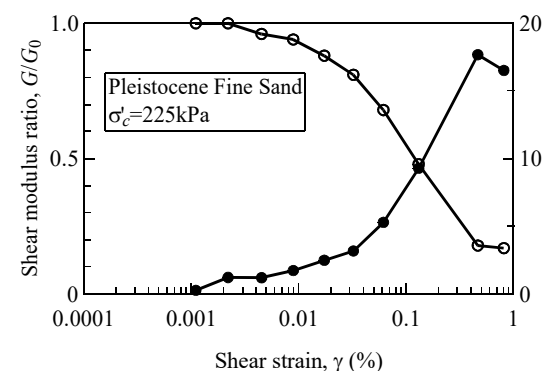

(a)繰返しせん断特性

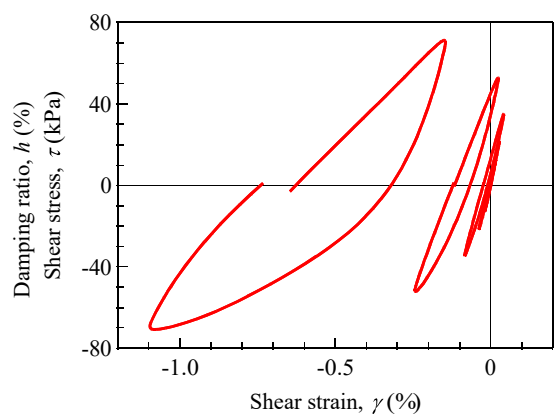

(b) 原点を初期に揃えた

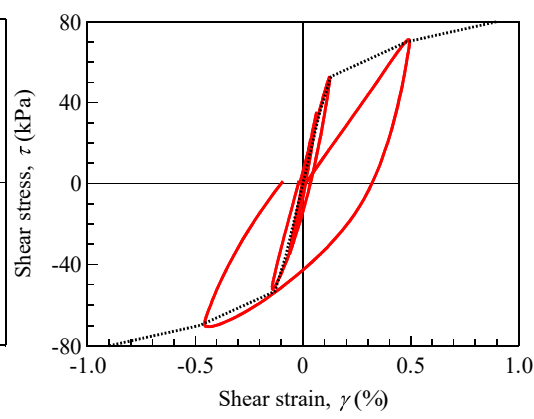

(c) 出力されるせん断特性

図-2 整理方法の矛盾 
が必要である。

\section{d) 等方応力状態の初期応力状態}

実地盤は，異方応力状態にある．水平成層でも軸差 せん断があると，初期せん断があるので，等方応力状態 とは応力一ひずみ関係が異なるはずである.

図-3(a)は $K_{0}$ 状態と現在よく行われる等方応力状態で試 験を比較したもので，等方応力状態の試験で良いという 証拠となっている. しかし，図-3(b)に示す，この実験時 の応力ーひずみ関係は全く異なっている. すなわち, 図 -3(a)は10サイクル目の形状がほとんど同じであることを 示しているのみで, 残留変形は考えられていない.

\section{e) ステージ間の排水}

現状の試験では，非排水試験でも，ステージ間で排 水しているため，材料は次第に密になる．このことをよ り明瞭にするために, 液状化強度試験と比較してみたの が図-4である．繰返しせん断試験では10サイクルまでの 載荷履歴はあるので，必要な繰返し数に対する履歴曲線 からひずみと応力を求めることができる. 図はそれを液 状化強度試験の結果と比較している. なお, 眓に表され ているひずみ/ 5 \& は片振幅せん断ひずみであり, 液状化 強度試験の結果も片振幅で整理されている.

同じせん断ひずみで見ると, 繰返しせん断試験の結 果の方が液状化強度試験の結果より大きな強度を示して いる.これは，繰返しせん断試験ではステージ間で排水 しているため, 試料が密になっていると考えれば理解で きる．砂では密度が異なると挙動が異なることはよく知 られているので, 得られた繰返しせん断特性は載荷前に 想定した材料のそれとは異なっている.

液状化強度試験と繰返しせん断試験では同じひずみ を比較しているとはいえ，そこに至る載荷履歴は異なる ので，その違いも試験結果に影響していることは考えら れるが，主要因は密度の違いと考えている.

\section{f) G/G0- $\gamma, h-\gamma$ 関係亡しての表示}

$G / G_{0}-\gamma$ 関係から $\tau-\gamma$ 関係を作ることは可能である. しか し, 履歴曲線は $h$ で表現されているだけでは, 形状を求 めることは出来ない. 履歴曲線の形状が紡錘型をしてい るのであれば，形状としてとり得る選択肢が多くないの で，解析結果にあたえる履歴曲線の形状の影響は小さい という報告はある11)。しかし，一方ではひずみが大きく なると砂質土では逆 $\mathrm{S}$ 字型の履歴曲線となり減衰定数が ひずみと共に小さくなる現象もあり，常に履歴曲線形状 の影響がないとはいえない.

もう一つの問題は，減衰定数はひずみエネルギーに 対する履歴吸収エネルギーの比であり，ひずみエネルギ 一の評価（ $G-\gamma$ 関係の評価）に依存して值が異なる．従 って, 解析で咸衰定数 $h$ が実験值と同じといってもエネ ルギ一吸収量が同じであるわけではない. 骨格曲線（ひ ずみエネルギー）も合っていて初めてエネルギ一吸収量

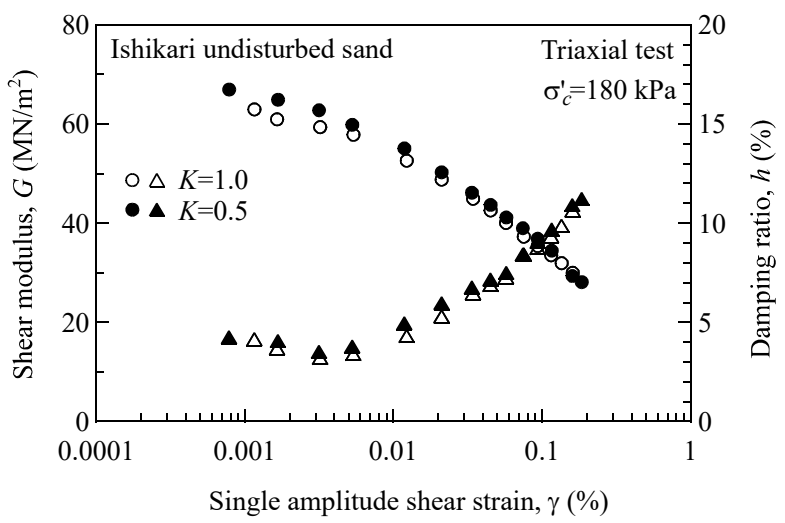

(a) 繰返しせん断特性の比較9)
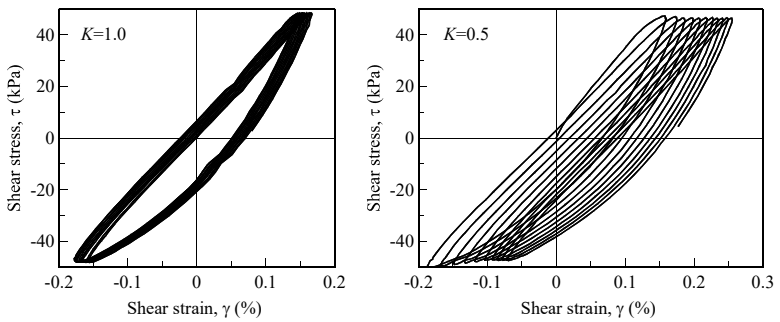

(b) 応力比一ひずみの関係の比較

図-3 $K_{0}$ の影響

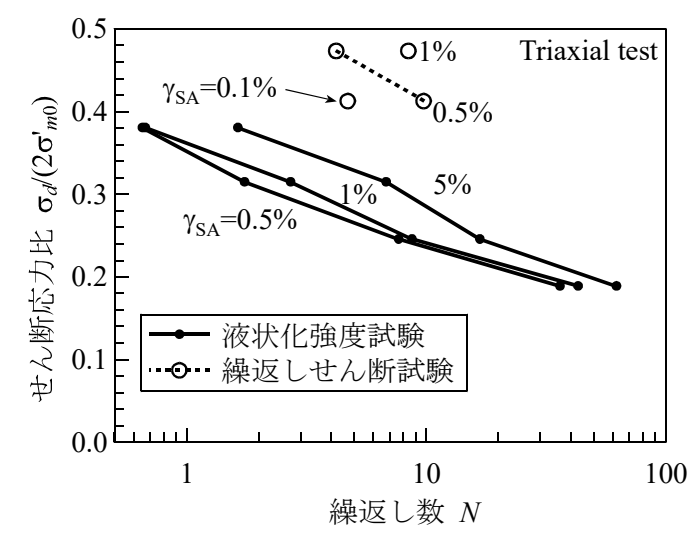

図-4 液状化強度試験と繰返しせん断特性試験の比較 ${ }^{10)}$

も合っていることになる.

\section{g) $G-\gamma$ 関係は骨格曲線か?}

図-5で，破線（青色）は排水による単調載荷実験，点 線（赤色）は非排水による単調載荷実験の結果である. また，実線は，ひずみ振幅制御で，前のステージのひず み振幅の10倍のひずみまでひずみを大きくした結果であ る ${ }^{12)}$. 図-5(a)はひずみ振幅を $1 \%$ から $10 \%$ 大きくしたもの であるが，これだけひずみを大きくしても応力ーひずみ 関係は単調載荷の結果と同じではない. 図-5(b)はひずみ をより小さいひずみで， $0.01 \%$ から $0.1 \%$ に大くした結 果であるが，この場合でも単調載荷の結果とは一致しな い. この例はひずみを10倍にしているが，現行の試験で はひずみはこれより小さい2倍程度を目標にしているの で，当然，履歴曲線は骨格曲線には到達しない.

一方，構成モデルでは，基本的に， $G-\gamma$ 関係を単調載 


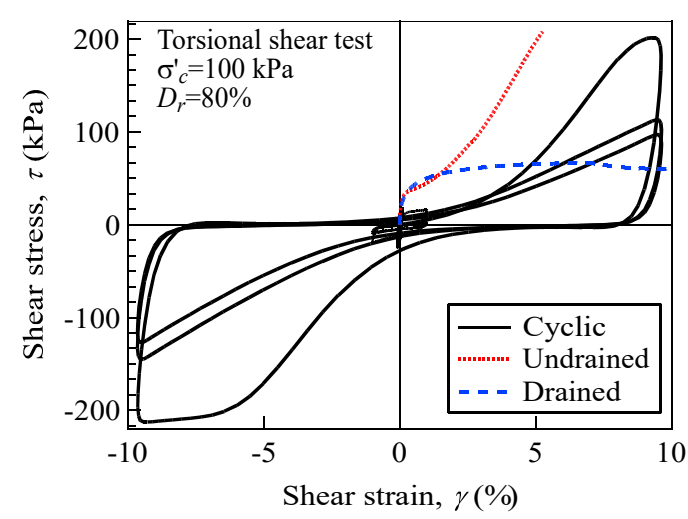

(a)ひずみを $1 \%$ から $10 \%$ に増加

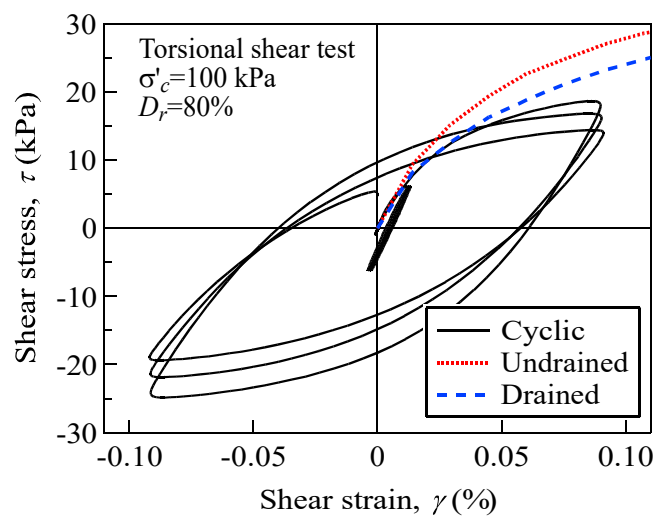

(b)ひずみを $0.01 \%$ から $0.1 \%$ に増加

図-5＼cjkstart単調載荷と繰返し載荷の低ひずみ時の比較

荷時の応力ーひずみ関係としてとらえているが，これは 実験結果とは対応しない。

\section{h) 載荷速度}

図-6は同じ材料，試験条件を異なる4つの試験機関で 行った際の液状化強度の比較である ${ }^{13}$. 液状化強度で倍 程度の差があるが，この原因は，試験機の能力によると 考えられる. 寸なわち, 液状化時の挙動のうち, 応力が ほとんど0の状態で大きなひずみが発生する領域では, ひずみ速度が大きくなるので, 試験機にこのひずみ速度 に対応する載荷能力がないと静的載荷であれば達するで あろう本来のひず夕に至る前に次の応力増分が設定され， 試験機では新しく設定された応力を計測值として出力す るので，応力を過大評価することになる，なお，図-6は 液状化強度試験であるが，繰返しせん断試験でも大ひず み領域では問題になる可能性がある.

これを避けるには, 載荷速度をゆっくりとすること である. また，どの程度の載荷速度が適当かは，それぞ れの試験機の能力によって異なるであろうから, 載荷速 度を変えた実験を行って, 適当な載荷速度を見つけてお くことが必要である.

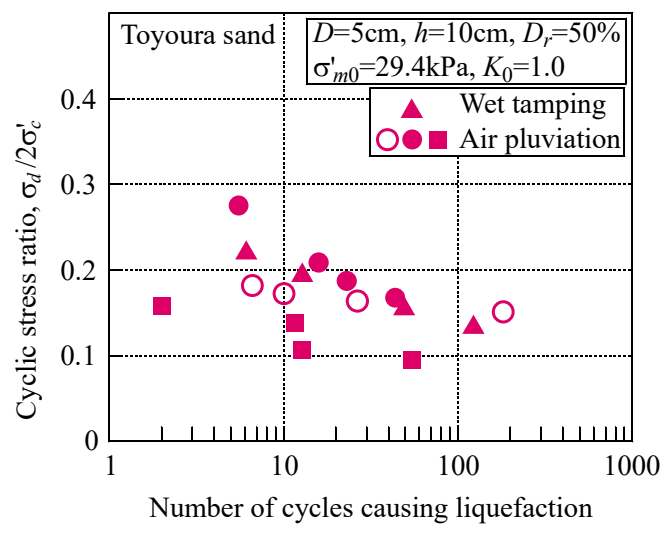

図-6 液状化強度の比較

\section{3. 提案する試験法}

前章で述べたように，現在一般的に用いられている 繰返しせん断試験の方法は，多くの問題点を抱えている. この試験法が提案された当時は, 解析法としては SHAKE に代表される等価線形解析に用いられることを 前提とされ, また, 入力地震動もそれほど大きくないこ とから，特に問題として意識されることがなかったため と考えられる. しかし, 現在のように, 逐次積分法に基 づき, 応力ーひずみ関係を逐一追跡する, 非線形法に適 用し，さらに，設計用入力地震動も非常に大きくなった 現在では，前章で述べたような不都合が出るわけである.

そこで，ここでは，現行の方法に代わる試験法を提 案する. なお，2章でも述べたように，文献1)には「繰 返しせん断試験」には多様な試験法が可能であり，ここ で示す方法も，その選択肢の中にあり，その意味では新 しい試験法というわけではない. 多様な方法が可能な文 献1)の中で標準的に用いる載荷方法を提案するものであ る.

近年，特に液状化に関しては非常に多くの構成モデ ルが提案されている. それらの構成モデルに用いられる パラメータは，よく知られた強度定数などの物理量以外 のモデル独自のパラメータが使われる事もある. そのよ うな構成モデルを用いる場合には，ここで提案する標準 法と異なる試験が必要になることもある. その意味で, ここで提案する試験法は，これだけ行えば十分という物 ではなく, 共通して実験データを蓄積していくため, 最 低限しておくべき試験法との位置づけである.

現在の試験法は，長い間使われてきているので，こ れと全く異なる新しい方法というのは，使う側も抵抗が 大きいと考えられる. ここで提案する方法は，文献1)の 範疇であるし，なるべく既存の試験結果と整合するよう な試みもしている.

表-1に提案する方法と現行の方法を比較して示す. 以 下，それぞれの項目について，その設定理由や現行の試 
表-1 二つの試験法の比較

\begin{tabular}{|c|c|c|}
\hline 項目 & 現行の方法 & 提案法 \\
\hline 振幅の設定 & 応力振幅 & ひずみ振幅 \\
\hline 載荷方法 & 応力制御 & ひずみ制御注1) \\
\hline $\begin{array}{l}\text { ステージ間のひず } \\
\text { み振幅 }\end{array}$ & $\begin{array}{l}\text { 前ステージの2 } \\
\text { 倍を目安 }\end{array}$ & 各桁, $1,2,5$ \\
\hline 載荷速度 & $0.1 \mathrm{~Hz}^{\text {注2) }}$ & $\begin{array}{l}\text { 速度依存性が表れ } \\
\text { ない速度 }\end{array}$ \\
\hline $\begin{array}{l}\text { ステージでの繰返 } \\
\text { し数 }\end{array}$ & $10^{\text {注3) }}$ & 3 \\
\hline ステージ閒の排水 & あり & なし \\
\hline 実験終了の目安 & $\begin{array}{l}\text { 履歴挙動の非定 } \\
\text { 常化 }\end{array}$ & $\begin{array}{l}\text { 試験機の能力で可 } \\
\text { 能な限り大ひずみ } \\
\text { まで }\end{array}$ \\
\hline
\end{tabular}

注1）小さいひずみ領域では，応力制御でも可能

注2）文献1)では0.05Hz〜 $1 \mathrm{~Hz}$ を標準としている.

注3）11サイクルの載荷の10サイクル目の履歴曲線を用いる.

験との差などを示す.

\section{（1）載荷方法}

小さいひずみ振幅では応力制御，大きいひずみ振幅 ではひずタ制御とする.

ひずみ振幅制御とすると，ひずみが大きくなると発 生する2.(2) h)で述べたような載荷速度の影響を減らすこ とができる．ただし，先に述べたように，試験機の能力 を超えるひずみ速度で載荷することはできない，ひずみ 振幅制御，ひずみ制御とすることで，必要なひずみ速度 の值は簡単に計算できる。これを試験機で可能な能力

（ひずみ速度）と比較し，もし，試験機の能力が不足す る場合には，載荷速度を遅くして試験を行うことができ るという長所もある.

なお，ひずみが非常に小さい間は，ひずみ制御の試 験は計測器の分解能 (精度) の都合から困難なことも多 い. そこで，小さいひずみ域ではより制御の容易な応力 制御で行っても良いことにした。載荷法の切り替えは, $\gamma=0.01 \%$ を超える頃に行うのが適当と考えられる. これ は，これ以上のひずみでは過剩間隙水圧が発生するため， 載荷法の違いが試験結果に影響を及ぼす可能性があるか らである。

なお，ひずみ制御試験では，小さいひずみ域と大き いひずみ域でひずみの増分值が異なるようにしないと， 試験時間が非常に長くなる可能性がある，従って，応力 制御の元で，現在行われている周波数 $0.1 \mathrm{~Hz}$ の載荷方法 と同じように周波数で載荷方法を設定する方法は好まし くなく，ひずみ速度を元にした載荷速度の設定が必要と なろう。すなわち, 現行の試験法では静的な挙動を求め
ることを目的としているので，載荷速度を変えても同じ 挙動となるような速度で載荷すべきであり, 試験機関で は試験により適切な載荷速度を決めるための試みを行う べきである.

\section{(2) 初期応力状態}

原位置の応力状態を初期応力状態とする方が好まし いことは言うまでもない. 三軸試験装置を用いて $K_{0}$ 圧 密を行う試験法は基準化されているので，技術的には可 能といえる.しかし，サンプリングによる乱れの影響が あるため, この試験で得られた $K_{0}$ 值が原位置の $K_{0}$ 值で あるかどうかはわらかない。

原位置で $K_{0}$ を求める方法として，ディラトメーター やセルフボーリングプレッシャーメーターを用いる方法 もあるが，孔壁の乱れ等の影響を受けるため，測定值の 確からしさはわからない14). 凍結サンプリングによる試 料を用いて求める方法も提案されている ${ }^{15}$ が，コストを 考えると実用的とはいえない.

このように，原位置で $K_{0}$ を精度よく計測することは 困難である．また，初期せん断応力を求めることも困難 である。

次に仮に， $K_{0}$ が得られたとしても，室内試験で $K_{0}$ 状 態を実現するのは困難である．側方ひずみを拘束して圧 密載荷すると，K0は自動的に決まってしまうので，設定 した $K_{0}$ の值にすることはできない，また，初期応力状 態を異方応力状態に設定することは可能であるが，その 状態から載荷しても，原位置の状態とは一致していると は限らない.

これらを考えると原位置の応力状態を再現する最善 な初期応力状態というのは実現が困難である．適当な $K_{0}$ を仮定して実験をするよりも等方応力状態にして実験 を行う方が設定しやすい応力状態と考えられる. なお, 初期の等方応力状態は現行の試験でも初期有効上載圧で 載荷することが推奨されており，ここでもこれを推奨す る. もう一つの可能性として，初期有効拘束圧を原位置 と同じにするという方法があるが，そのためには静止土 圧係数の值が必要であることに加え, 鉛直方向について は有効上載圧から応力が減少するために過圧密の状態に なっているという問題もあるからである.

\section{(3) ひずみ振幅制御}

載荷振幅は，現行の方法では応力振幅を設定するこ とが多いが，ここでは，ひずみ振幅で設定することを提 案する.ひずみ振幅制御は現行の方法に比べていくつか の長所がある.

応力振幅制御試験では，次のステージの振幅は現在 のひずみ振幅の倍のひずみを目標としているが，ひずみ が大きい領域では材料特性の非線形性のために少しの荷 
重の差が大きなひずみの差となるので，この制御はかな り困難で, 試験者により試験結果に差が出る事が一般的 である。しかし，ひずみ制御試験とすることで，試験者 による差が生じない試験をする事ができる。これが一つ 目の長所である.

繰返しせん断試験に用いられる試験機には，三軸装 置，中空ねじり装置，単純せん断装置などがあるが，実 用を考えると，三軸装置しか選択肢は無さそうである. 三軸試験を前提とすると，応力振幅制御ではひずみのド リフト（ラチェッティング）が発生する.このため, 現 行の方法では, 図-2に示したように, 性能設計で重要な 残留ひずみを無視して, 繰返しに伴う履歴曲線のみを扱 うという，無理と思える処理をしているが，ひずみ振幅 で定義することにより，全ての履歴挙動よりせん断特性 を求めているので，既往の応力制御の試験で発生してい た残留ひずみの問題は生じない.これがひずみ振幅制御 の二つ目の長所である.

図-7はひずみ振幅制御で，次のステージの増分を1桁

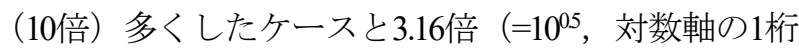
を2等分）したケースを比較したものである．ひずみが 大きいところでせん断岡性に差が見られるが，これはひ ずみ増分が小さいと同じひずみでもより多くの繰返し載 荷を受けているので，劣化が進んでいるためである．両 者を比較すると，実験值からなめらかな曲線を得るため には，増分を 1 桁とするのは，大きすぎ，最低限 0.5 桁は 必要な様に見える．また，文献1)ではひずみ振幅は前ス テージの2倍を推奨している．これらを考え，ひずみ振 幅は各桁で，1，2，5のひずみとすることにする．する と，ひずみは前回の2〜2.5倍の間にあるので，現行の試 験法とほぼ整合している.

なお，ひずみ振幅制御試験では，三軸装置を用いる と，ひずみは対称であるが，応力は非対称となる。 この 場合には，圧縮側，伸張側それぞれのせん断岡性を出力 しておくことが望ましい. また，現行法のように除荷点 を結ぶ直線の傾き（割線剛性）として出力寸る事も可能 であろう。

\section{(4) 繰返し数}

前述のように，最大応答が発生するのは，ひずみが 新しい領域に入ったときであると考えられるので，1サ イクル目の挙動が重要である. しかし，1サイクル目の 載荷だけであると, 劣化の程度を評価することは困難で ある.また，前報るで示したように，現行の方法である 10サイクル目の挙動とは大きく異なっている.

これまでにも述べたように，現状の10サイクル目とい うのは，履歴曲線が安定する事を目標に決められたもの であり, 力学上必然性があるという訳でもない.

構造工学の他の分野, 例えば, やはり劣化現象が見

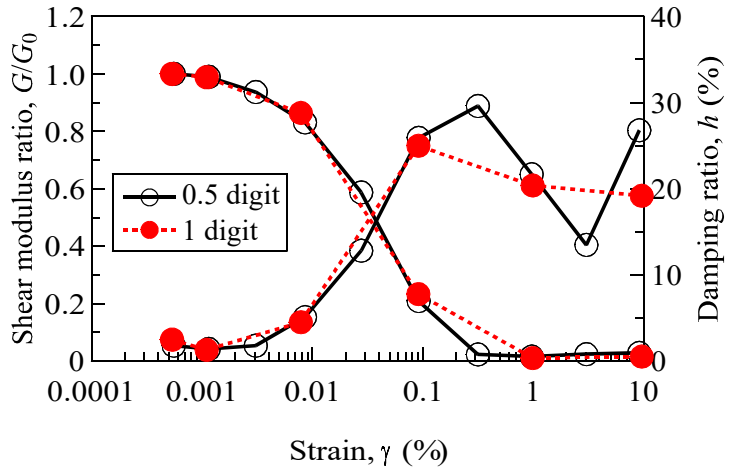

図-7 ひずみ振幅の違いの影響

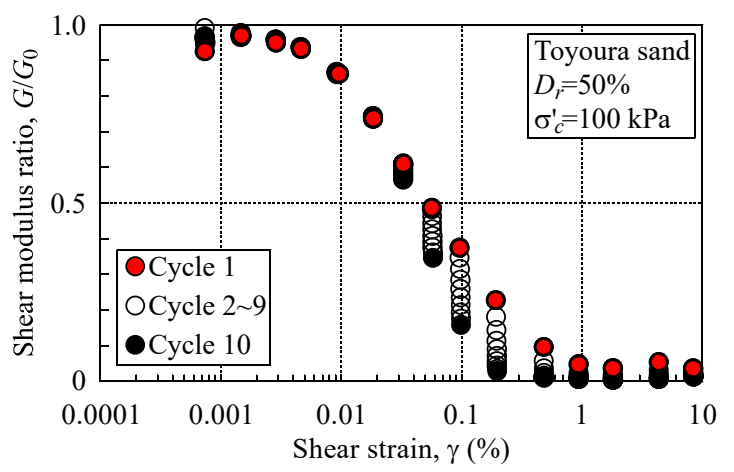

図-8 繰返し数の影響

られるコンクリート構造物などでは，変位振幅制御で3 サイクルの載荷が行われる事が多いので（例えば文献 16)），ここでも同じ繰返し数と設定した. 図-8は繰返 しに伴うせん断岡性比の変化を示したものであるが, $G / G_{0}=0.5$ 程度までは繰返し数による影響は見られないの で，現行の試験法と整合性がある.

また, 繰返し数が増えると, 履歴の影響がより大き くなるので，あまり繰返し数を多くしない方が良い．し かし，一方では繰返しに伴う劣化の影響も把握すること が必要である. 設定した載荷方法はこの両者の均衡をと ったものである.

\section{(5) 非排水試験}

従来の試験でも非排水試験が行われてきた。ただし， ステージ間では発生した過剩間隙水圧を消散させている. これは，各ステージの初期応力状態を同じにするという 発想と考えられる.

しかし，ステージ間で排水すると，試料は次第に密 になっていく. 図-9は初期相対密度 $50 \%$ の試料の密度が 載荷とともに変化していく様子を示したものである.ひ ずみ振幅が $0.1 \%$ では密度の変化は小さいが，ひずみが 1\%を超えると，10サイクル載荷では密度の増加も53\%か ら66\%以上で20\%程度以上となる. 図-10は図-9と同じ試 験の各ステージにおける過剩間隙水圧の発生量を示して いる. ひずみ振幅 $0.1 \%$ （サイクル数にもよるが）初期 有效拘束圧の $50 \%$ 程度の過剰間隙水圧が発生している. 


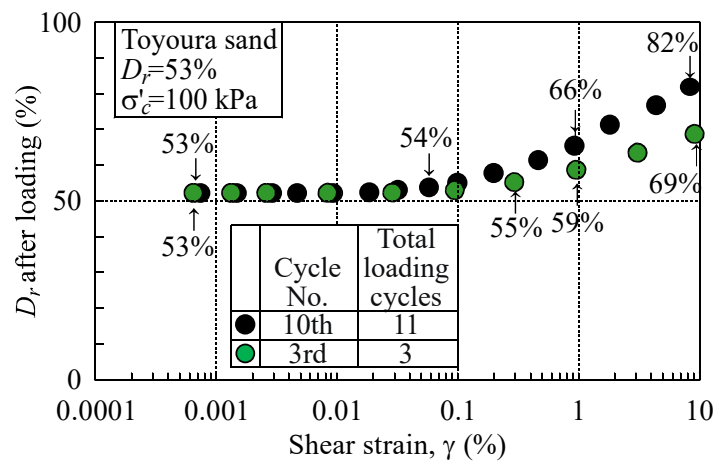

図-9＼cjkstart排水による相対密度の変化

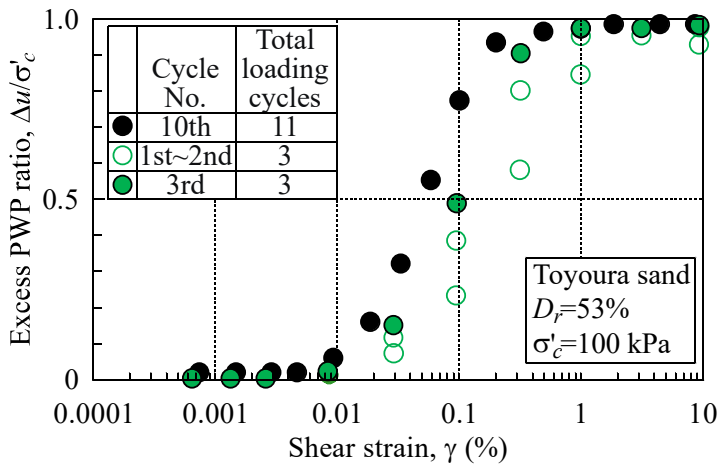

図-10 過剩間隙水圧の発生量

この問題は，同じ初期状態をとるか，同じ相対密度 をとるかという選択の問題である。 そこで，現行の構成 モデルを概観すると，体積変化に伴う密実化をきちんと 追跡できるモデルはほとんどない，ステージ間で非排水 とすると，載荷の履歴は残っているので，多くの構成モ デルでそれらを追跡することも可能である.

図-11はステージ間で排水したときと，排水しなかっ たときの挙動を比較したものである. $G / G_{0}=0.5$ 程度まで では，両者の差はほとんど見られない。しかし $G / G_{0}=0.5$ が0.5より小さくなると，載荷ステージ間で供試体の非 排水状態を保った試験では剛性は非常に小さくなってい る.

次に，図-12は，既往の方法（各ステージ11サイクル 載荷で10サイクル目の履歴曲線，ステージ間排水）と提 案法に近い条件（各ステージ3サイクルの載荷で3サイク ル目の履歴曲線，ステージ間も非排水。ひずみ振幅制御 ではない事が提案法と異なっている）を比較したもので, それぞれ，Conventional，New として示されている. New では，繰返し数を少なくし，履歴の影響を抑えたことに より，現行の試験法の適用限界（0.1\%よりやや大きいひ ずみ）までの挙動では，提案する手法は，既往の試験結 果とも整合性が高い結果となっている，なお，図-12で は差が無いように見えるがこれはたまたまであり，これ より大きいひずみでは常にこのようになるわけではない また，次節で示寸図-13の様に既往の方法より多くの情 報を出力しており，これらが挙動を把握するために重要 であることが本論文の主張である，従って，単に図-12
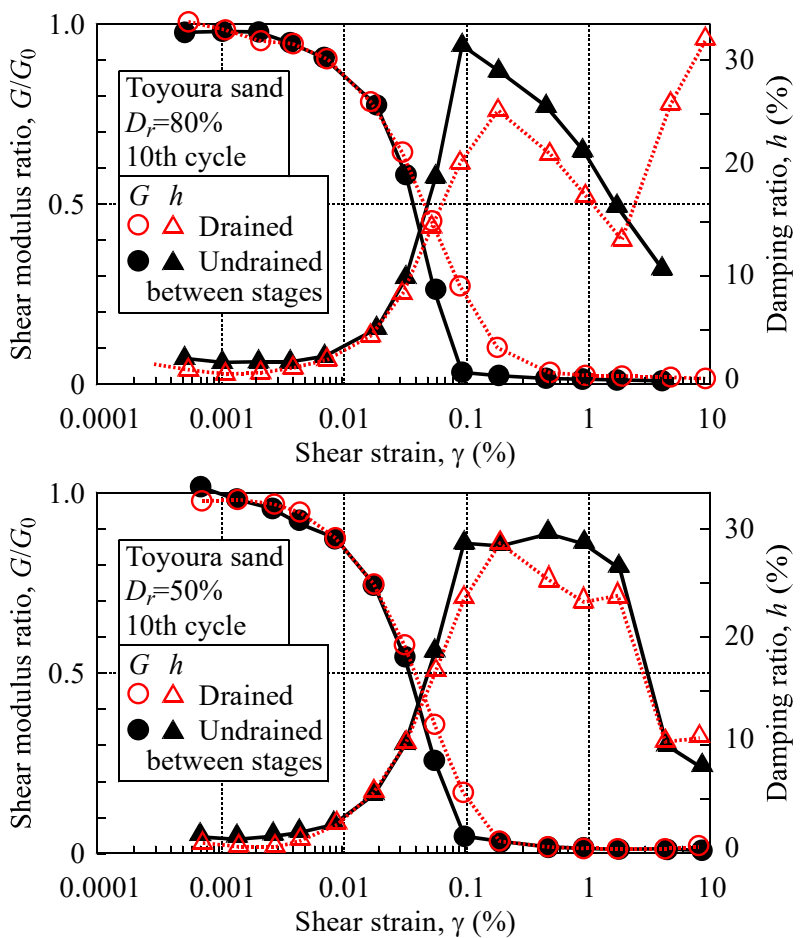

図-11 ステージ間排水の影響
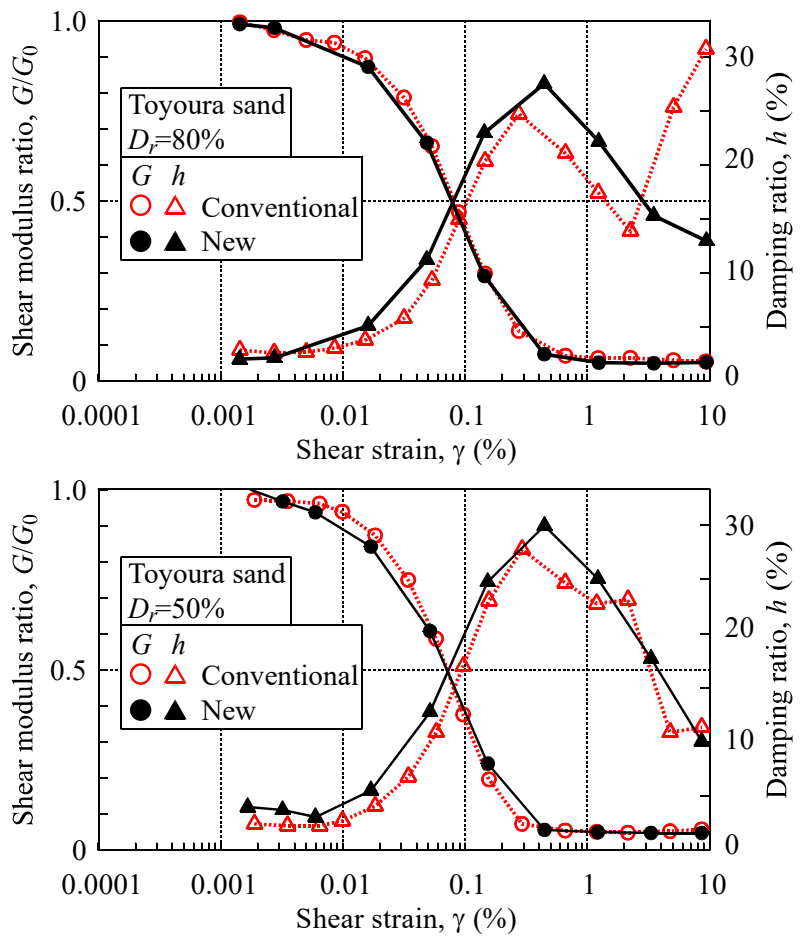

図-12 ステージ間排水と繰返し数の影響

が一致しているように見えるだけで，既往の方法でも良 いといっている訳ではない.

\section{(6) 出力}

各サイクルの $G$ と $h$ ，および過剩間隙水圧の発生量を 出力する. 提案する方法に基づく出力の例を図-13に示 す.

ここで，G- $\gamma$ 関係， $h-\gamma$ 関係については試験そのものの 目的であるから出力するのは当然で，全てのサイクルの 
值を出力するのも，載荷による（主として過剩間隙水圧 の発生による）劣化を定量的に考慮するために必要であ る. また，過剩間隙水圧の出力は，過剩間隙水圧の発生 による劣化を検討するために必要なものである.

\section{(7) その他}

繰返しせん断強度試験（液状化強度試験）は，繰返 しせん断試験のフレッシュテストと同じ実験である．従 って, 液状化強度試験のある応力振幅における挙動と, 繰返しせん断試験における同じ（程度の）応力振幅の挙 動を比較することによって, 繰返しせん断試験のこのス テージに至るまでの載荷が繰り返しせん断挙動に与える 影響を見ることが可能である。

\section{4. 全応力解析との関係}

全応力解析（ダイレイタンシーを考えない解析）で は, 繰返しせん断試験で得られたせん断岡性と減衰定数 のひずみ依存性を応力一ひずみ関係として用いるのが一 般的であった. しかし，これまでに示したように， $G / G_{0}$ が0.5を下回る程度から，過剩間隙水圧の発生が無視で きなくなり, 全応力解析の前提条件とは適合しなくなる. また，ステージ間で排水を行う現行の試験は，大ひずみ 域では，全応力解析で想定している状況と大きく異なる 条件で実験をしていることになり，問題がある.

これは試験法の問題ではない. 非排水状態で実験を すれば，過剩間隙水圧の発生は避けることができないし， 排水状態で実験すれば，試料の密実化は避けることがで きない. すなわち, 全応力解析で想定している, ダイレ イタンシーの起こらない実験を行うことは不可能である。 そこで, 解析者は, 実験結果から解析に用いる応力一ひ ずみ関係を抽出すべきである.

ひずみが大きくない場合には，過剩間隙水圧の発生 などはあまり問題にならなかったことから，実験結果を そのまま解析に用いる応力一ひずみ関係として使うこと に問題はなかった. しかし, 設計用入力地震動が大きく なると，発生するひずみも大きくなり，本論で述べてき たような載荷履歴の影響が顕在化する様になった。 した がって, 解析者は, 実験結果を基に解析で用いる応力一 ひずみ関係を求める必要がある. その方法は, 構成モデ ルによって異なるであろうから，本論では論じない。

実験をひずみ振幅制御で行うことによって，これま での繰返しせん断試験の適用範囲とされる，0.1\%を少し 超えるひずみ領域よりはるかに大きいひずみまで試験を する事が可能である．図-5では10\% のひずみまでの試験 が行われているが, 試験機の能力があれば, これ以上の ひずみでも試験は可能である. しかし，これを持って， 全応力解析がこの様に大きいひずみまで啇用可能である
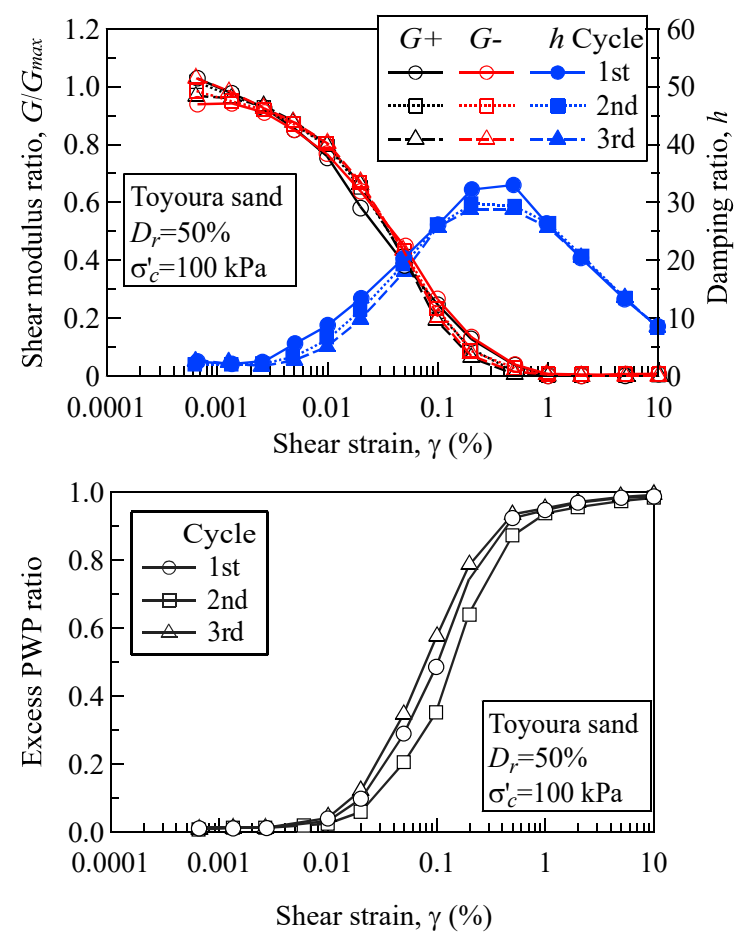

図-13 結果の出力例

と判断しない注意が必要である.

非線形解析で応力ーひずみ関係を作るとき，G- $\gamma$ 関係 を初期載荷状態の応力一ひずみ関係（骨格曲線）, $h-\gamma$ 関係が履歴曲線に対応するとしてモデルが作られていた。 しかし，図-5に示されるように， $G-\gamma$ 関係は単調載荷時 の応力ーひずみ関係とは一致しない. 構成モデルでこの 様な効果が考慮できる様な研究が進められることを希望 する.

\section{5. おわりに}

地盤の地震応答解析に用いるために現在標準的に行 われている試験法の問題点を指摘し，これに代わる標準 的な試験法を提案した. この方法は，ひずみ振幅制御で 各ステージ3サイクルの載荷を行うこと，ステージ間で 排水を行わないこと，ひずみ制御で載荷すること，など が現行の方法と異なっている. なお，現行の試験法の適 用限界と考えられるひずみまでは現行の試験法による結 果と整合性がある.

この試験法は，土の力学特性の基本的な情報を得る ものであり, 解析で用いる構成モデルによってはさらな る試験が必要かもしれない. なお，この試験法は主とし て過剩間隙水圧の発生による影響を論じていることから 対象としているのは砂やシルトである. 粘性土について も同様な観点からの検討は必要と考えるが，現状では提 案できるだけのデータは持っていない，礫については提 案法が適用できると考えられるが，具体的に実験を行っ ているわけではない. 
また，従来，繰返しせん断試験の適用範囲と全応力 地震応答解析の適用範囲は同一視されることが多かった が，ここで提案する方法ではそのようなことはない. 載 荷は大ひずみまで行うことが可能であるが，その結果を 全応力解析によ゙のように用いるかは，解析者の判断であ る.これについては，今後の研究が期待されるところで ある.

2.(2)の最後で, 減衰定数で表す問題, $G-\gamma$ 関係と骨格 曲線の対応の問題に触れたが，これらは本提案法でも解 決できたわけではない. 今後の研究課題となると考えら れる.

本研究は, 小委員会のメンバー (委員長 : 吉田 望 （boh070949@gmail.com），副委員長：渦岡良介，幹 事 : 三上武子, 委員 : 飛田 善雄, 一井康二, 大矢陽介, 矢部正明，塩見忠彦，上田恭平，仙頭紀明，市川卓也， 兵頭 順一，金田一広）による議論をまとめたものであ る.

\section{参考文献}

1）地盤工学会室内試験規格・基準委員会 : 地盤材料試験 の方法と解説 訂正第2刷, 地盤工学会, 1156pp., 2010 .

2) Schnabel, P. B., Lysmer, J. and Seed, H. B.: SHAKE A Computer program for earthquake response analysis of horizontally layered sites, Report No. EERC72-12, University of California, Berkeley, 1972.

3) 土木学会・地震工学委員会・性能設計に対応した繰返 しせん断試験検討小委員会 : 性能設計のための土の繰 返しせん断試験の標準化 その1 解析側から見た問題 点，土木学会論文集 C, Vol. 75, No. 2, pp. 146-154, 2019.

4) Seed, H. B. and Idriss, I. M.: Soil moduli and damping factors for dynamic response analyses, Report No. EERC70-10, UCB, 40pp., 1970.

5) Hardin, B. O. and Drnevich, V. P.: Shear modulus and damping in soils: measurement and parameter effects, Proc. of the ASCE, Vol. 98, No. SM6, pp. 603-624, 1972.

6) Hardin, B. O. and Drnevich, V. P.: Shear modulus and damping in soils: design equations and curves, Proc. ASCE, Vol. 98, No. SM7, pp. 667-692, 1972.

7) Ishihara, K.: Evaluation of soil properties for use in earthquake response analysis, Proc., Int. Symp. on Numerical Models in Geomechanics, Zurich, pp. 237-259, 1982.

8）地盤工学会・大ひずみ領域の研究の必要性, 大ひずみ を考慮した土の繰返しせん断特性に関するシンポジウ 厶, 2013.

9) 山下聡，稲原英彦，土岐祥介：等方および異方圧密時 の砂の繰返し三軸変形特, 第30回土質工学研究発表会, pp. 889-892, 1995.

10) 吉田望, 三上武子 : 時代の要請に応える土の繰返しせ 儿断変形特性試験の確立を, 地盤工学会誌, Vol. 8, No. 2, pp. 1-5, 2010.

11) 吉田望, 澤田純男, 竹島康人, 三上武子, 澤田俊一： 履歴減衰特性が地盤の地震応答に与える影響, 土木学 会地震工学論文集，第27巻，Paper No. 158， 2003.

12) 吉田望, 三上武子, 澤田純男, 規矩大義 : 地盤の地震 応答解析のための土の動的変形特性試験の提案, 第40 回地盤工学研究発表会講演集, pp. 459-460, 2005.

13）鈴木貴志, 竹信正寛, 菅野高弘, 中澤博志：FLIP に おけるパラメータの設定法の違いが動的解析結果に及 ぼす影響, 第5 回地盤工学会関東支部発表会, pp.239242, 2008.

14) Mori, H.: Study on the properties of soils in the northern coast of Tokyo Bay using a self-boring pressuremeter, Soils and Foundations, Vol. 21, No. 3, pp. 83-98, 1981.

15) Hatanaka, M. and Uchida, A.: A simple method for the determination of $K_{0}$-value in sandy soils, Soils and Foundations, Vol.36, No.2, pp.93-99, 1996.

16）日本道路協会 : 道路橋示方書 - 同解説 $V$ 耐震設計に 関する参考資料，丸善，302pp.，2015.

\section{地震工学委員会}

性能設計に対応した繰返しせん断試験検討小委員会

吉田 望（委員長），渦岡 良介（副委員長），三上 武子（幹 事), 一井康二, 市川 卓也, 上田 恭平, 大矢 陽介, 金田 一広, 塩見 忠彦, 仙頭 紀明, 兵頭 順一, 飛田 善雄, 矢部 正明

(2018.4.2 受付) 